\title{
ETIOLOGICAL AND MOLECULAR BIOLOGICAL INVESTIGATION OF CAPRINE HERPESVIRUS 1 ISOLATED IN BULGARIA ${ }^{1}$
}

\author{
Raiko Peshev, Ivo Sirakov, Nedelcho Nedelchev, Stoil Karadzhov \\ National Diagnostic and Research Veterinary Medical Institute \\ "Prof. d-r. G. Pavlov", P. Slaveikov 15, Blvd., Sofia, Bulgaria
}

\begin{abstract}
From goat and bucks with genital disorders and abortions the attempts for isolation of caprine herpesvirus 1 (CHV 1) were carried out. For virus exaltation Dexametazone was used. For viruses isolation vaginal, nasal, rectal, preputial swabs and organ samples were used. Primary and continuous cell cultures rabbit kidney (RK), Madin Darby bovine kidney (MDBK), and embrional bovine trachea (EBTR) were used for cultivation. For determination of DNA type and lipid envelop $60 \mu \mathrm{g} / \mathrm{ml}$ iod desoxiuridine (JDUR) and the ether treatment was used. Neutralization by specific hyperimmune serum obtained from Switzerland was performed. Five CHV 1 strains were isolated by cell cultures and identified as goat herpesviruses from different Bulgarian regions. After electron microscopy the viral agents with typical size and morphology for herpesviruses were established. For demonstration gC gene of $\mathrm{CHV}$ 1 the polymerase chain reaction (PCR) with primers designed from sequences deposited in gene bank were developed. Isolated on cell cultures herpesviruses were proved as caprine herpesvirus 1 by using applied PCR variant. The products after gC gene amplification from Bulgarian isolates were separated on the same place as the amplicons of reference CHV 1 strains.
\end{abstract}

Key words: CHV 1, PCR method, gC gen

1 Rad je saopšten na 8. kongresu veterinara Srbije, 15-19. septembra 2009. godine, Beograd 


\section{ETIOLOŠKO I MOLEKULARNO-BIOLOŠKO ISTRAŽIVANJE KOZIJEG HERPESVIRUSA 1 IZOLOVANO U BUGARSKOJ}

\section{Kratak sadržaj}

Kod koza i jaraca sa genitalnim poremećajima i abortusima pokušali smo da izolujemo koziji herpsevirus 1 (CHV 1). Za reaktivaciju virusa korišćen je Dexametazon. Za izolaciju virusa korišćeni su vaginalni, nazalni, rektalni i prepucionalni bris. Za izolaciju - kultivaciju virusa su se koristile primarne i kontinuirane kulture ćelija bubrega zeca („rabbit kidney - RK”), bubrega goveda („Madin Darby bovine kidney - MDBK”) i embrionalne traheje goveda („embrional bovine trachea - EBTR”). Za određivanje DNK tipa i lipidnog omotača upotrebljeno je $60 \mu \mathrm{g} / \mathrm{ml}$ jod dezoksiuridina (JDUR) i tretiranje etrom. Urađena je neutralizacija specifičnim hiperimunim serumom koji je dobijen iz Švajcarske. Pet CHV 1 sojeva iz različitih oblasti Bugarske je izolovano na kulturama ćelija i identifikovano kao koziji herpesvirus. Nakon elektronske mikroskopije virusni agensi tipične veličine i morfologije su prepoznati kao hepresvirus. Za dokazivanje gC gena $\mathrm{CHV} 1$ upotrebljena je lančana reakcije polimeraze (PCR) sa prajmerima koji su dizajnirani na osnovu virusnih sekvenci prijavljenih u banci gena. Upotrebom primenjene PCR tehnike, na kulturi ćelija izolovani herpesvirusi su potvrđeni kao koziji herpesvirus 1 . Sekvence umnoženih gC delova genoma bugarskih izolata su se locirale na istom mestu u filogenetskom stablu kao i sekvence referentnih CHV 1 sojeva.

Ključne reči: CHV 1, PCR metod, gC gen

\section{INTRODUCTION}

Caprine herpesvirus 1 (CHV 1) is a DNA containing virus with a diameter 120-150 $\mathrm{nm}$ and lipid envelope. The antigenic peculiarity of virus is not well studied. According to Engels et al. (1987) viral DNA has a high homology with bovine herpesvirus 1 DNA. After investigation of agent by neutralization test, ELISA and restrictase fragment pattern analysis is determined that CHV 1 is immunologically different from herpesviruses in big ruminants and elks $(5,10,18)$. Glycoproteins with molecular weight 74 and $91 \mathrm{kD}$ are responsible for cross neutralization between bovine and caprine herpesvirus. Despite the differences in molecular weight it was de- 
termined by PAGE that the polypeptides of goat and bovine herpesviruses have similar mobility (2).

The first report for CHV1 comes in early 1974 from Saito et al. (13) in California who described the disease with high percent mortality among angora goats. In young animals CHV 1 caused generalized infection damaging gastrointestinal and respiratory tracts (1). Macroscopically are visible ulcer and necroses in all gastrointestinal channels, changes in lungs, urinary bladder and liver. Pathohystologically are observed heavy necrotizing enteritis, as well as thickening of alveolar septa and necrotic bronchoalveolitis (12). Clear microscopic damages are observed also in liver, urinary bladder, spleen, thymus, mesenterial lymph nodes and kidney. The disease is accompanied with diarrhea, rhinitis, tracheitis, breathing disturbance and later supurative nasal discharges.

In bucks the virus caused balanopostitis and penopostitis and in goats vulvovaginitis $(8,14,15)$. From damaged genital tract the infection is transmitted by breeding. Abortions are observed, too $(17,19)$.

The number of isolated CHV 1 in the world is limited. Some parts of epidemiology, pathogenesis and spreading of the disease are not well elucidating. This is the reason to isolate etiological agent and study the cultural and genome characteristics.

In this paper is described the isolation and identification of CHV 1 causing goat infection and by using the physicochemical and molecular biological methods to study some biological peculiarity of the virus.

\section{MATERIAL AND METHODS}

Nasal, vaginal and preputial swabs, lung lavages, $10 \%$ suspension in phosphate buffered saline (PBS) from internal organs, probang test, buffy coats, fecal and milk samples were used for virus isolation. Totally 163 samples were checked. The samples originated from several country regions: Troian, Suhindol, Kustendil, P.Bania, Smolian, Haskovo, Yambol.

For herpesvirus isolation the method for exaltation by dexamethasone (DMSO) was used (3).

\section{Cell cultures, media and solutions}

For virus isolation and identification of viruses primary and permanent cell cultures were used. The primary cell cultures were obtained newborn rabbit kidney and as permanent cell lines Madin Darby bovine kidney (MDBK), (AUBEK), Georgia bovine kidney (GBK), embryonic bovine trachea (EBTR) and calf trachea (TTr). For washing cell culture PBS with $\mathrm{rN} 7.4$ or normal saline were used. As growing media Eagle's Minimum Essential Medium (MEM) in Hanks balanced salts solution supplemented with $10 \%$ fetal calf sera (FCS) and as a supportive media the same media with $2 \%$ FCS were used. As additives penicillin $100 \mathrm{UI} / \mathrm{mL}$, streptomycin $100 \mathrm{\gamma} / \mathrm{mL}$, $0.2 \mathrm{M} / \mathrm{L} \mathrm{L}$ - glutamine and $\mathrm{NaHCO}_{3}$ were added. 


\section{Isolation and identification of CHV 1 on cell cultures}

For infection cell cultures with complete monolayer were used. After elimination of media and washing with PBS or normal saline $0.2 \mathrm{~mL}$ virus inoculums were added. Depending on the type of samples adsorption varied between 60 and $120 \mathrm{~min}$ at temperature of $37^{\circ} \mathrm{S}$. After washing of cell monolayers and adding the maintaining media the tubes were placed in a roller at $37^{\circ} \mathrm{S}$. Simultaneously, with the investigated samples non infected control cells were used in the same condition.

Microscopically, the isolates growth was controlled daily by determination the presence of cytopatic effect (CPE) on monolayers. In attempts for primary isolation the cell cultures were observed microscopically 7 days after the infection. Three consecutive passages were performed when CPE was missing and more passages - when $\mathrm{CPE}$ was visible. Because of the difficulties connected to the primary isolation of $\mathrm{CHV}$ 1 other methods for cultivation were used - infection on fresh monolayer, young $24 \mathrm{~h}$ cell cultures or in cell suspension.

Identification of viral agents in the infected cell monolayers with CPE were accomplished by the methods described by Payment and Trudel (1993). To determine the nucleic acid type the viral isolates were treated with $60 \mathrm{\gamma} / \mathrm{mL}$ 5-jodo-2-deoxyuridine (JDUR), and for lipid presence treated with $20 \%$ ether.

In neutralization reaction $\beta$-variant the reference hyperimmune sera from Switzerland had titer of $8 \log _{2}$. The obeseved CPE was similar to CHV. The serum participated in maintain media at constant dilution 1:4, and investigated isolates in 10 times increasing dilution. As control the reference CHV 1 strain $\mathrm{E} / \mathrm{CH}$ with a titer $10^{7.33}$ $\mathrm{TCID}_{50} / \mathrm{mL}$ on MDBK was applied. As control heterologous RNA strain paramyxo parainfluencae 3 virus "Svetovrachene" strain was used.

\section{Electron microscopy}

Electron microscopy investigation was performed with direct electron microscopy (DEM) after slow speed centrifugation of viral isolates $2000 \mathrm{rpm} / 20 \mathrm{~min}$. Supernatants were differentially centrifuged for $1 \mathrm{~h}$ at $30000 \mathrm{xg}$ and the obtained pellet were dissolved in minimal volume sterile distilled water $-0.5 \mathrm{ml}$, after which new slow speed centrifugation was carried out at $2000 \mathrm{rpm} / 20 \mathrm{~min}$. For performance of DEM the clear supernatants were added onto butvar and carbon coated cooper grids with 400 mesh and negative staining were performed with $2 \%$ sodium phosphovolframate $\mathrm{rN} 5.8$ or $2 \%$ uranil acetate $\mathrm{rN} 4.2-4.5$.

The investigations were carried out by electron microscope JEM 1200 EX with accelerated tension $80 \mathrm{kV}$ and instrumental enlargement 40000 to $75000 \mathrm{X}$.

\section{Molecular biological investigation}

The viruses were cultivated in cell culture and in $80 \%$ visible CPE they were harvested. Commercial kit GIAamp DNA mini kit Giagen, GmbH, Hilden Germany was used for isolation of DNA following the kit instruction. The DNA amount was con- 
trolled spectrophotometrically with Jenway apparatus (Genova) and by gel electrophoresis and was amplified by polymerase chain reaction (PCR) using the following pairs of primers corresponding to sequences $759-779$ and 1172-1154 from the gene bank:

Forward R 1 ' ' AGGGCGCCGGTGGATGCTCTG - 3'

Reverse $\mathrm{R}_{2}$ 5' - GGCGGGCGGTGCGTCGTGA - 3'

Reaction was conducted in a volume of $25 \mu \mathrm{L}$, using Fidely tag PCR Master mix (2X), forward primer $\mathrm{P}_{1}$, reverse primer $\mathrm{P}_{2}$ and DNA template. Thermocycler QB 96 (LKB) and the program described from Hecht et al. (1995) were used for PCR reactions.

Heated lid $110^{\circ} \mathrm{C}$

1 cycle

Denaturation $96^{\circ} \mathrm{C}-10 \mathrm{~min}$; Annealing $65^{\circ} \mathrm{C}-1 \mathrm{~min}$; Elongation $72^{\circ} \mathrm{C}-1 \mathrm{~min}$.

Following from 35 cycles

Denaturation $95^{\circ} \mathrm{C}-1 \mathrm{~min}$; Annealing $65^{\circ} \mathrm{C}-1.30 \mathrm{~min}$; Elongation $72^{\circ} \mathrm{C}-1 \mathrm{~min}$.

Final Elongation at $72^{\circ} \mathrm{C}$ for $5 \mathrm{~min}$.

DNA extraction and PCR products were electrophoresed on $2 \%$ agaroza with ethidium bromide $(1 \mathrm{mg} / \mathrm{ml})$ and were visualized by UV transiluminator. For PCR specificity closely related IBR "Ozet" strain were included.

Serological investigation by micro virus neutralization test (MVNT)

Sera from goats with clinical symptoms typical for CHV 1 infection and recovered were investigated for antibodies against $\mathrm{CHV} 1$ by micro virus neutralization test (MVNT) - $\beta$ variant. The sera were temperature treated at $56^{\circ} \mathrm{S}$ for $30 \mathrm{~min}$, after that serial two fold dilution in maintenance media MEM Eagle, penicillin $100 \mathrm{UI} / \mathrm{mL}$, streptomycin $100 \mu \mathrm{g} / \mathrm{mL}, 2 \mathrm{mM} / \mathrm{L}$ L-glutamin, $1.5 \mathrm{~g} / \mathrm{L}$ sodium bicarbonate were performed. Hundred tissue culture infectious dose $50 / \mathrm{mL}\left(\mathrm{TCID}_{50} / \mathrm{mL}\right)$ from reference strain $\mathrm{E} / \mathrm{CH}$ with a titer $10^{7.3}$ was added to dilute sera. The mixtures were incubated at $37^{\circ} \mathrm{S}$ for $2 \mathrm{~h}$. After that the indication system - cell line MDBK at quantity $4 \mathrm{~h} 10^{-4}$ cells/mL was added.

The account of results was performed till $72 \mathrm{~h}$. The highest dilutions of sera giving complete growth suppression of indicator virus were accepted as serum titer.

\section{RESULTS}

Viral agents were isolated only after dexametazone treatment from animals with antibodies against CHV 1. The viruses were isolated only from vaginal and preputial swabs. The virus isolates have cultural and biochemical characteristics typical for caprine herpesvirus 1. From goats and bucks with problems in breeding 5 CHV 1 strains were isolated: Troian, Suhindol, Kustendil, P. Bania and Biser.

The citopatic effect on primary and permanent cell cultures depended on used cell lines and started with rounding of cells. Between 6 and $12 \mathrm{~h}$ after infection of monolayers only single cells were rounded. Cytopatic effect on $24 \mathrm{~h}$ became more diffuse and great number of cells was damaged (Fig. 1A) after which the speed changes 
on monolayers were visible. At $48 \mathrm{~h}$ on cell monolayers were observed extended empty places as a result of the viral growth (Fig. 1B) and after $48 \mathrm{~h}$ the part of cell monolayers was detached from the tube walls and after $72 \mathrm{~h}$ a destruction of monolayers was visible (Fig.1 C). In control non infected MDBK cell cultures the cytopatic effect was not observed (Fig. 1 D)

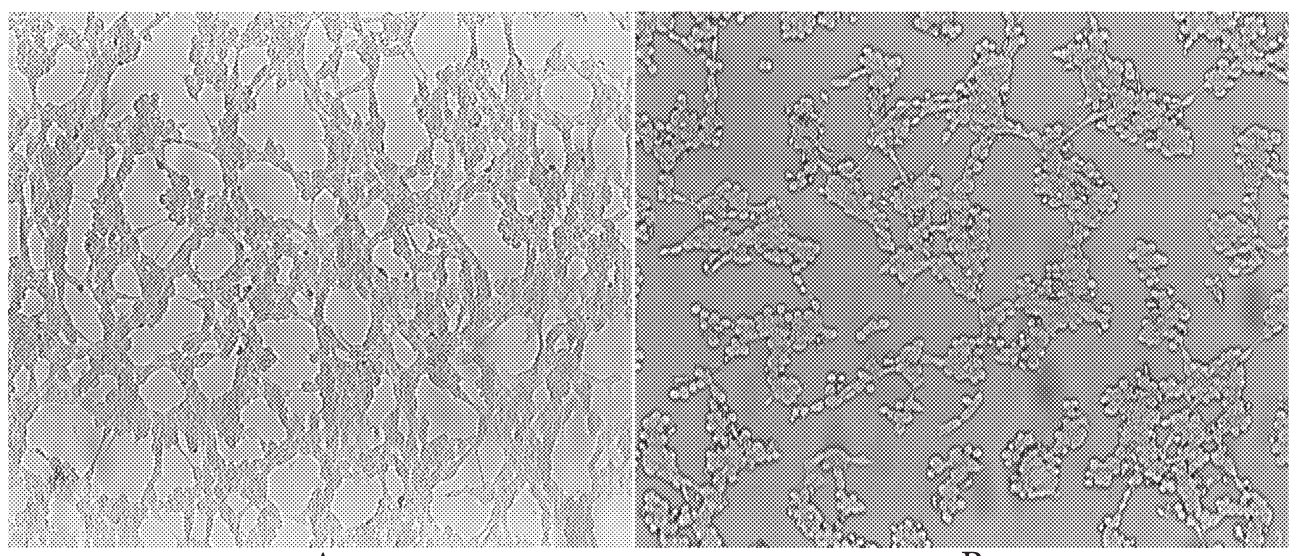

A

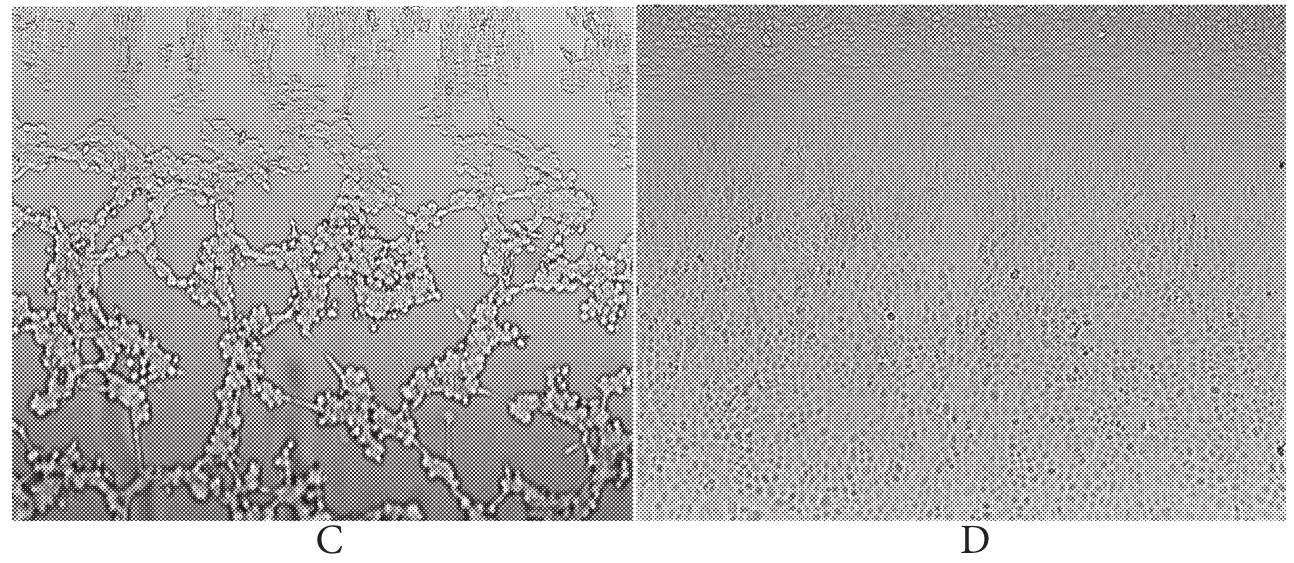

Fig. 1. Cytopatic effect of isolate "Suhindol" on cell culture MDBK: A - $24 \mathrm{~h}$ after infection, B - $48 \mathrm{~h}$ post infection, C - $72 \mathrm{~h}$ after infection, D - control non infected cell culture MDBK. Magnification - $200 \mathrm{H}$.

The obtained results during investigation for identification of agents in infected cell cultures are shown in Table 1. 
Table 1. Data from biochemical and molecular biological studies for determination of nucleic acid type, effect of HIS against CHV 1, presence of lipid coat, impact of low and high $\mathrm{pH}$ buffers with five $\mathrm{CHV} 1$ isolates, reference $\mathrm{E} / \mathrm{CH}$ strain and heterologous Pi-3 strain "Svetovrachene".

\begin{tabular}{|c|c|c|c|c|c|}
\hline \multirow{2}{*}{ Sample } & \multicolumn{5}{|c|}{ Strain titration after treatment with } \\
\cline { 2 - 6 } & $\begin{array}{c}\text { Titers before } \\
\text { treatment }\end{array}$ & $\begin{array}{c}60 \gamma / \mathrm{ml} \\
\text { JDUR }\end{array}$ & $\begin{array}{c}\text { HIS anti } \\
\text { CHV 1 }\end{array}$ & $\begin{array}{c}20 \% \\
\text { ether }\end{array}$ & $\begin{array}{c}\text { Buffer } \\
\text { with } \mathrm{rN}<3 \text { and }>8\end{array}$ \\
\hline goat"Troyan" & $10^{-7.32}$ & $10^{-3.0}$ & $10^{-1}$ & - & - \\
\hline 7892 goat "Suhindol" & $10^{-6.33}$ & $10^{-2.33}$ & $10^{-1.50}$ & - & - \\
\hline buck "Kustendil" & $10^{-5.66}$ & $10^{-2.0}$ & - & - & - \\
\hline buck"P. Bania" & $10^{-6.33}$ & $10^{-3.0}$ & - & - & - \\
\hline buck"Biser" & $10^{-4.66}$ & $10^{-2.0}$ & - & - & - \\
\hline Referent strain E/SN & $10^{-7.33}$ & $10^{-2.33}$ & $10^{-1.33}$ & - & - \\
\hline Pi-3 "Svetovrachene" & $10^{-5.33}$ & $10^{-5.33}$ & $10^{-5.33}$ & - & - \\
\hline
\end{tabular}

After treatment with $60 \mathrm{\gamma} / \mathrm{mL}$ 5-jodo-2-deoxyuridine (JDUR) for the determination of nucleic acid type in 5 isolates a suppression of growth with more than $3-4 \log _{10}$ was established. In treatment of referent strain E/SN a suppression of growth - $5 \log _{10}$ in comparison with non treated virus. Suppression of viral titer was not found in RNA strain Paramyxovirus PI-3 "Svetovrachene". After neutralization test with positive hyperimmune sera from Switzerland in all new isolated strains a suppression between 4-6 $\log _{10}$ was obtained. In reference strain $\mathrm{E} / \mathrm{CH}$ also was determined reduction in viral titer with $6 \log _{10}$. In heterologous strain "Svetovrachene" such decrease in viral titer was not observed.

The five isolates, referent $\mathrm{E} / \mathrm{CH}$ and control RNA viral strain were not growing on cell culture after treatment with $20 \%$ ether.

After electron microscopy the viral particles with diameter approximately 150-180 $\mathrm{nm}$ and typical for herpesviruses morphology were observed (Fig. 2).

Fig. 2. Electron microscopy of viral isolate "Suhindol". With arrows are noted viral particles.

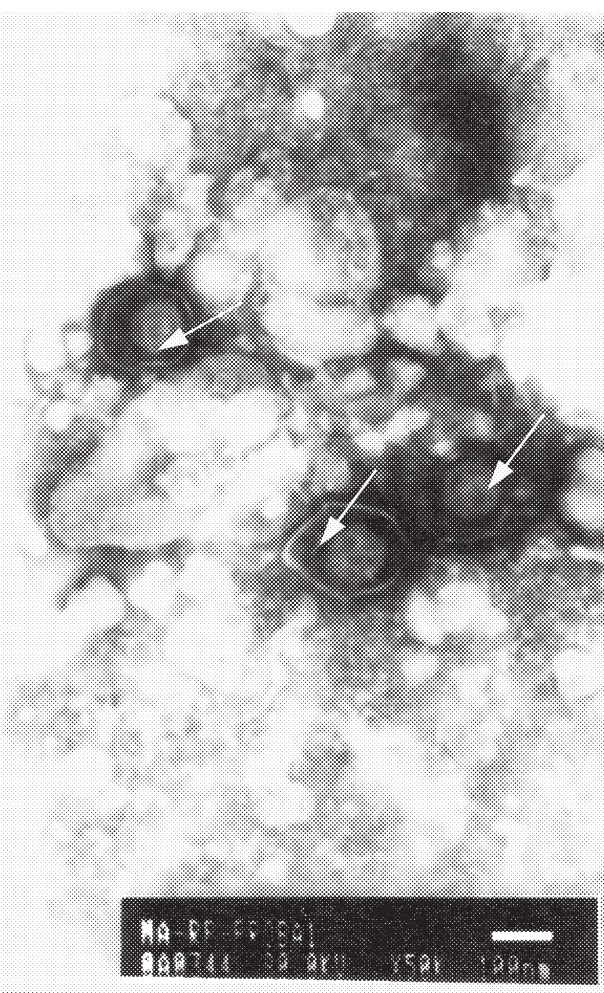


In molecular biological investigation the quantity of DNA obtained by Giagen columns varied between $163.5 \mathrm{ng} / \mu \mathrm{l}$ and $198.2 \mathrm{ng} / \mu \mathrm{l}$. After using PCR master mix with the described program multiplication of gC gene was possible. Products with size 414 $\mathrm{bp}$ for all 5 caprine herpesviruses isolated in Bulgaria and for all reference strain from Europe and USA were obtained after performing PCR reaction (Fig. 3). There was not multiplication of genome of investigated IBR "Ozet" strain in using the same primers and procedure for PCR specificity.

Fig. 3.

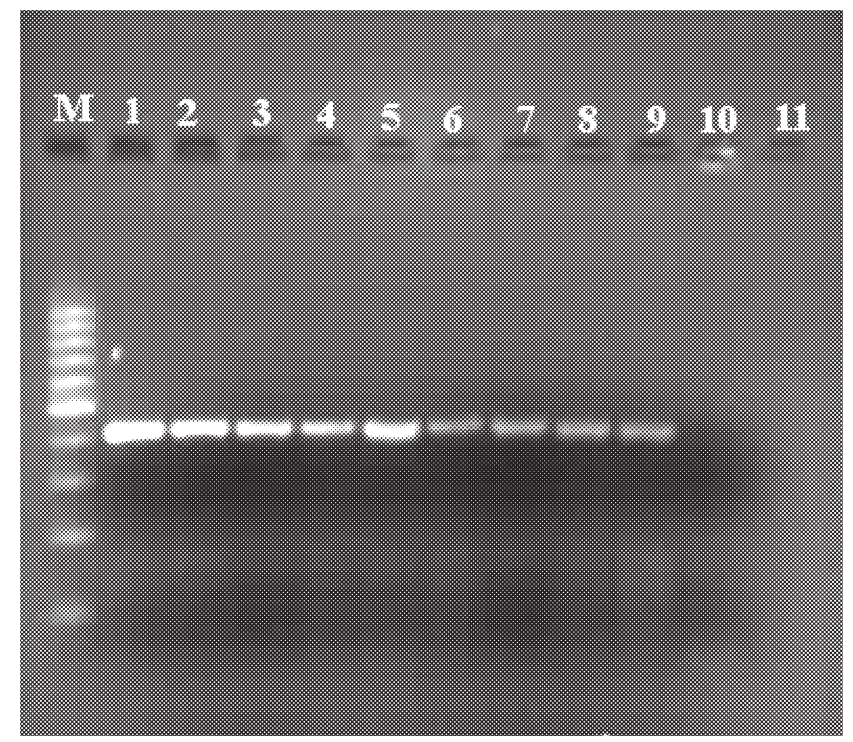

Fig. 3. Polymerase chain reaction of 5 Bulgarian isolates and reference $\mathrm{CHV} 1$ strains. Lane M, 1-kb ladder as a size marker, lane 1-"Troyan", lane 2-"Suhindol", lane 3-"P. Bania", lane 4-"Kustendil", lane 5-"E/CH", lane 6-"McKercher", lane 7-"Sp-1", lane 8-"Sp-2", lane 9-"Biser", lane 10-"IBR-Ozet", lane 11-non infected cell culture -MDBK.

After serological investigation in five country regions from which the viruses were isolated an increase of antibody titers two and more $\log _{2}$ in paired sera was determined against referent E/CH strain (Fig. 4). 


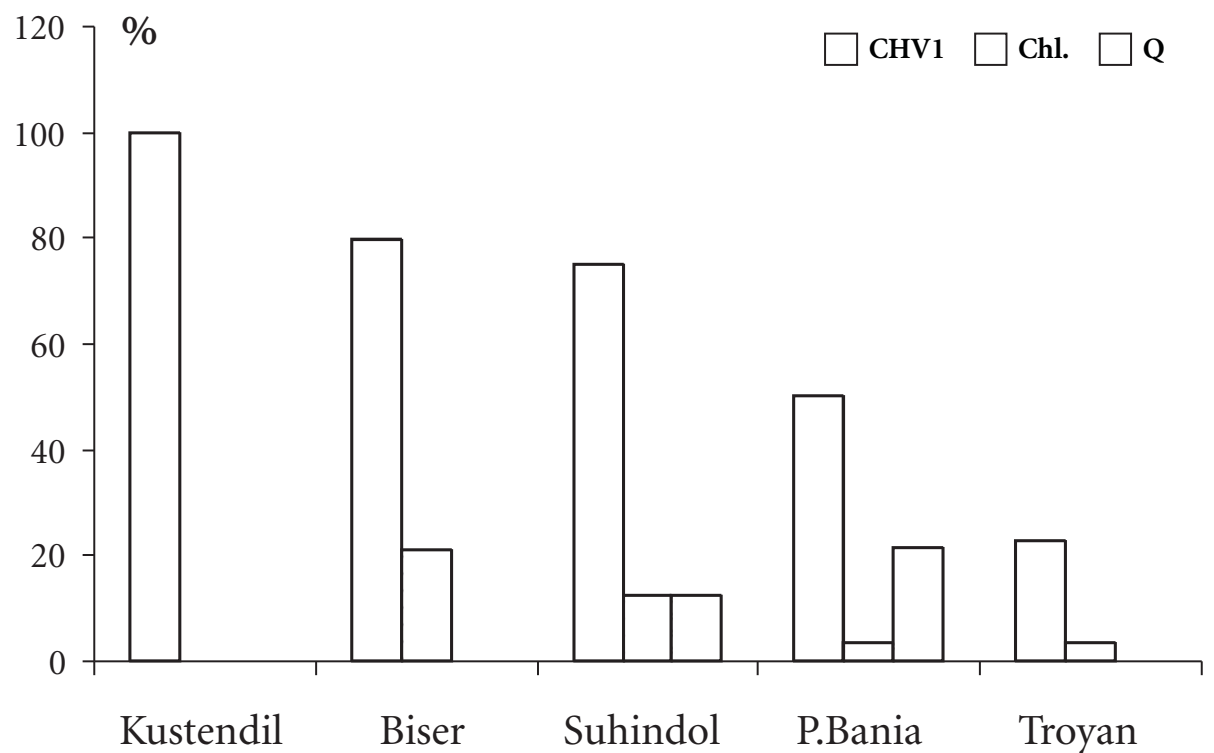

Fig. 4. Percent distribution of positive serum samples against referent $\mathrm{E} / \mathrm{CH}$ strains and Chlamydophilla and Q-fever in investigated flocks.

The highest percent positive sample in Kustendil (100\%) followed by Biser (79.9\%), Suhindol (75\%), P. Bania (50\%), and Troian (22.75\%) were found (Fig. 4). The number of positive bucks increased after breeding campaign, and also the titer of antibodies was increased in comparison with antibody titers before the campaign. In some goats were determined repeating twice and three time heat especially in Troyan, Suhindol and P. Bania farms. Additionally titers against chlamidophilla pursue infection were determined for Troyan (3.44\%), Suhindol (12.5\%), P. Bania (3.57\%), Biser $(21 \%)$ and against coxiella burnety in Suhindol (12.5\%) and P. Bania (21.42\%) only.

\section{DISCUSSION}

Using the scheme (Buonavoglia et al., 1996) for exaltation of caprine herpesvirus 1 we succeed to isolate five CHV 1 strains from vaginal and preputial swabs. The virus isolated only from vaginal swabs, but not from nasal, rectal swabs and buffy coat. The isolation of goat and bucks viruses was possible with high DMSO doses between 3 and 9 days after finishing the treatment of positive for antibodies animals. Smaller DMSO doses were not enough for virus isolation.

The cytopatogenic effect in the adaptation and cultivation of strains was with mild changes with rounding of the cells after that the monolayer was destructed as described by Engels et al. (1983) changes. The grow rate of new isolated CHV 1 strains by us was more rapid in comparison with that of bovine herpesvirus 1 as Engels et al. (1983) established for CHV 1 strain. After latent period of $5 \mathrm{~h}$ exponential phases of virus growing 6 to $12 \mathrm{~h}$ after infection was observed. The cytopatic effect of isolated viral agents on cell cultures with rabbit and bovine origin was more diffuse than the 
bovine herpesviruses. Most probably that is the results of higher citolitic properties of CHV 1 in comparison with BHV 1.

After treatment with JDUR and the applying of MVNT with hyperimmune sera from Switzerland against reference CHV 1 strain the viral titers were decreased with more than $2-4 \log _{2}$. This is the evidence that the isolated viral agents were CHV 1 . The complete suppression of viral growth after treatment with ether confirmed that the new isolated samples and reference controls are with lipids bilayers of membrane. This is supported by the fact that the heterologous Pi 3 virus is suppressed from a treatment with $20 \%$ ether. At lower and higher $\mathrm{pH}$ solutions the growth of viral isolates is also suppressed. The probable reason for this is the repression of contacts between viral antigens and cell receptors and the impossibility for entrance and multiplication of causative agents in cell cultures.

At electron microscopy studies viral agents with typical size and morphology for herpesviruses were determined.

The observed biological peculiarities of all 5 Bulgarian isolates by performed PCR reaction similar to reference $\mathrm{CHV} 1$ strains $\mathrm{E} / \mathrm{CH}$ and McKercher are the evidence that all five isolates are CHV 1 strain. This permit us to conclude that PCR reaction with the described primers and procedures can be used for rapid and exact diagnosis.

After investigation by MVNT of sera originating from animals in acute and convalescent period of the disease from the five farms we detected an increase in antibody titers with two and more logarithms against reference CHV 1 strain which is an indication for CHV 1 circulation in flocks. On some farms the established antibody titers were a result of single infection, while on other farms it was accompanied with chlamydophilla and q-fever infections. The disease elapsed more heavily in the presence of these accompanying infections and recovering period of animals was long lasting and often in next breeding season the breedings were hampered.

\section{CONCLUSIONS}

1. Isolation and adaptation of five goat herpesviruses were possible only after treatment with DMSO.

2. CHV 1 viral strains can be successfully adapted on primar and permanent cell culture of bovine origin.

3. Isolated viral agents have cultural, biochemical and morphological characteristics typical for CHV 1.

4. The amplicons of all virus strain after performed PCR assay have the same size and mobility as the reference CHV 1 strains.

5. Statistically significant increasing of MVNT antibody titers in recovalescent sera is the evidence for circulation of CHV 1 on goat farms.

LITERATURE

1. Berrious P. E., McKercher D.G.: Characterization of a caprine herpesvirus. Am J Vet Res, 36, 12, 1755-62, 1975. 
2. Buddle B.M., Pfeffer A., Cole D.J.W., Pulford H.D., Ralston M.J.: A caprine pneumonia outbreak associated with caprine herpesvirus and Pasteurella haemolytica respiratory infection, New Zealand Vet J, 38, 28-31, 1990.

3. Buonavoglia, G., Tempesta, M., Cavalli, A., Voigt, V., Buonavoglia, D., Conserva, A., Corrente, M.: Reactivacion of caprine herpesvirus 1 in latently infected goats. Comp Immunol, Microbio and Infect Diseases 19, 257-281, 1996.

4. Chenier S, Montpetit C, Helie P.: Caprine herpesvirus-1 abortion storm in a goat herd in Quebec, Can Vet J, 45, 241-243, 2004.

5. Engels M., Gelderblom H., Darai G., Ludwig H.: Goat Herpesviruses: Biological and physicochemical properties, J Gen Virol, 64, 2237-2247, 1983.

6. Engels M, Loepfe E, Wild P, Schraner E, Wyler R.: The genome of caprine herpesvirus 1: genome structure and relatedness to bovine herpesvirus 1. J Gen Virol 68, Pt 7, 2019-23, 1987.

7. Hecht P., Engels M., Loepfe E., Ackermann M.: Comparison of glycoprotein gC genes of bovine and caprine herpesviruses. In: Immunobiology of viral infections. Proceedings of the $3^{\text {rd }}$ Congress of the European Society of Veterinary Virology, Interlaken, Switzerland, 147-152, 1995.

8. Horner G.W., Hunter R., Day A.M.: An outbreak of vulvovaginitis in goats caused by a caprine herpesvirus, NZ Vet J, 30, 150-152, 1982.

9. Metzler F., Engels M., Wild P., Bivetti A.: Herpesvirus - infection bei Zicklein in der Schweiz., Schweiz Arch Tierheilk, 121, 655-662, 1979.

10. Nixon P, Edwards S, White H.: Serological comparisons of antigenically related herpesviruses in cattle, red deer and goats. Vet Res Commun. 12, 4-5, 355-62, 1988.

11. Payment P., Trudel M.: Isolation and identification of viruses. In: Methods and techniques in Virology, New York: Marcel Dekker, 19-41, 1993.

12. Roperto F., Pratelli A., Guarino G., Ambrosio V., Tempesta M., Galati P., Iovane G., Buonavoglia C.: Natural caprine herpesvirus 1 (CpHV-1) infection in kids, $J$ Comp Pathol,122, 298-302, 2000.

13. Saito, J.K., Gribble, D.H., Berrios, P.E., Knight, H.D., Mc Kercher, D.G.: A new herpes virus isolate from goats: preliminary report, American Journal of Veterinary Research, 35, 847-848, 1974.

14. Tarigan S., Webb R.F., Kirkland D.: Caprine herpesvirus from balanopostitis, Austr Vet J, 64, 321, 1987.

15. Tarigan S., Ladds P.W.,Foster R.A.: Genital pathology of feral male goats. Austr Vet J, 67, 286-290, 1990.

16. Tisdall D.J., Bentley C.B., Collins D.M., Horner G.W.: New Zealand caprine herpesvirus: comparison with an Australian isolate and with bovine herpesvirus type 1 by restriction endonuclease analysis, New Zealand Veterinary Journal, 32, 99-100, 1984.

17. Uzal F.A., Woods L., Stillian M., Nordhausen R., Read D.H., Van Kampen H., Odani J., Hietala S., Hurley E.J., Vickers M.L., Gard S.M.: Abortion and ulcer- 
Arhiv veterinarske medicine, vol. 2, br. 2, 27-38, 2009.

Peshev R. et al.: Etiological and molecular...

ative posthitis associated with caprine herpesvirus-1 infection in goats in California, J Vet Diagn Invest, 16, 5, 478-484, 2004.

18. Whetstone C.A, Evermann J.F. Characterization of bovine herpesviruses isolated from six sheep and four goats by restriction endonuclease analysis and radioimmunoprecipitation. Am J Vet Res, 49, 6, 781-5, 1988.

19. Williams N.M.., Vicker M.L., Tramontin R.R., Petrites-Murphy M.B., Allen G.P.: Multiple abortions associated with caprine herpesvirus infection in a goat herd, J Am Vet Med Assoc, 211, 89-91, 1997.

Primljeno: 20.11.2009.

Odobreno: 23.11.2009. 